This is an electronic reprint of the original article. This reprint may differ from the original in pagination and typographic detail.

Author(s): Stark, Laura

Title: $\quad$ Voicelessness and the Limits of Agency in Early Modern Finnish Narratives on Magic and the Supernatural

Year: $\quad 2015$

Version:

Please cite the original version:

Stark, L. (2015). Voicelessness and the Limits of Agency in Early Modern Finnish Narratives on Magic and the Supernatural. Narrative Culture, 2(1), 117-140. https://doi.org/10.13110/narrcult.2.1.0117

All material supplied via JYX is protected by copyright and other intellectual property rights, and duplication or sale of all or part of any of the repository collections is not permitted, except that material may be duplicated by you for your research use or educational purposes in electronic or print form. You must obtain permission for any other use. Electronic or print copies may not be offered, whether for sale or otherwise to anyone who is not an authorised user. 
(last draft, Published in Narrative Culture 2:1, Spring 2015, 117-140)

Laura Stark

\section{Voicelessness and the Limits of Agency in Early Modern Finnish Narratives on Magic and the Supernatural}

Introduction: Self, Narrative and Voicelessness

Given that narrative research has shown narration to be an innate trait of the human species (Abbott; see also Barthes; Nussbaum 230), the concept of narrative culture encompasses a vast domain. Here I define it as a system of conventions ${ }^{2}$ for representing temporally ordered events, conventions that are shared by a group. Such groups tend to be coterminous with linguistic communities. This definition implies that the conventions of a given narrative culture that are intelligible to one group may not necessarily be intelligible to another. Narrative culture is historically transmitted and inherited and can change over time. According to Clifford Geertz (93), culture acts as a "model" in two senses, being both a "model of" and a "model for." In a similar fashion, narrative culture gives meaning or conceptual form to our social and psychological experience of reality by both reflecting the way in which its users understand themselves and the world around them and by shaping that understanding in the first place. This article is specifically concerned with the role of narrative culture in the social construction of self $^{4}$ and agency through narrative, what narrative theorist Martin Kreiswirth (309) calls the inquiry into "narrative identity": how we use narrative to construct our sense of ourselves as "developing moral agents, with pasts, presents, and futures." 
Narrative--by which I mean "a representation of events or series of events" (Abbott 12), is our only tool for understanding ourselves as agents operating through time (Abbott 3, 123). Conceptualizing our lives in terms of narrative thus facilitates the experience of self-continuity through time and explains why people have a tendency to perceive themselves as living out their lives in a temporally ordered narrative with a beginning, middle, and end. Referring to this need for self-continuity, Anthony Giddens (54) portrays self-identity as "the capacity to keep a particular narrative going."

However, if we want to express and describe our experiences to others and ourselves through language, we cannot do it in any fashion whatsoever. We use our cultural conventions of narration to convey our identities, our personal histories, more intelligibly to others, thereby constructing a coherent social reality. People also use the characters they encounter in narratives as a means to express their selfhood. These characters are always "flattened" and typecast, in contrast to the fully rounded, constantly changeable and phenomenologically complex persons encountered in real life, because narrative characters are functions of the cultural norms used to tell stories. Norms for what is internally possible in a story are in turn shaped by the kinds of agencies seen to be possible, probable, and acceptable in real life. Such on-the-ground theories of personhood encapsulated in narrative are not just ways of expressing reality, they also shape how we experience it (Harré 22, 193). We seek to model ourselves after the kinds of characters narratively possible in our culture, since these will be the stereotypes and storylines others recognize. The limits of our narrative traditions are thus the limits of our identity, as sociologist Nikolas Rose (237-78) explains: ${ }^{6}$

We use stories of the self that our culture makes available to us, with their scenarios of emotions, their repertoires of motives, their cast-list of characters, to plan out our lives, to account for events and give them significance, to accord 
ourselves an identity as hero or victim, survivor or casualty within the plot of our own life, to shape our conduct and understand that of others. ... Rules of this "grammar" of individuals--"language games"--produce or induce a moral repertoire of relatively enduring features of personhood in inhabitants of particular cultures, and one that has a morally constraining quality: we are obliged to be individuals of a certain sort.

This link between narrative and self is by now well established in numerous intellectual disciplines such as literary studies, folklore studies, oral history, and social psychology. By contrast, the relationship between self and narrative culture, if we assume each narrative culture to have its own criteria and standards for intelligible narration, deserves more attention. In the modern West, key elements necessary for constructing intelligible narratives include the notion of an authentic interiority legitimizing the individual as the fundamental unit of society, ${ }^{7}$ as well as the demands that follow from this assumption: accountability for past actions, and sticking for the most part to the objective facts of one's life story as others might describe them. In this way, narrators in a modern Western tradition construct a personal past that has validity and social currency.

Yet if the limits of our narratives serve as the limits of our identities, then it logically follows that different narratives (told in different cultures or at different times in history) will have produced different sorts of selves from those with which we are familiar. Even in the Western world, narrative conventions have changed over time; the most important shift took place when older forms of narrative, including what could loosely be termed allegory and epic, often conveyed orally, lost their status as authorized representations of reality. Whereas the identities of "premodern"8 persons were constructed in dialogue with these symbolic narratives, modern selves began to participate in narratives that placed value on personal, chronologically ordered memory, aided through the techniques of reading and writing. Allegory and epic were 
thus replaced by more "subjective" modes of narration--best characterized by the autobiography and the novel--in which the constantly shifting perspective of the individual was inserted into representation (Bakhtin; Swanson). According to John Lyons, in Europe until the mid-eighteenth century it was assumed that all thought and experience followed more or less the same paths as it had in the past, and that there was little possibility for individual deviance. Personal narratives, usually addressed to God, were highly formulaic and rooted in the idea of one individual "soul" being much like another. Additionally, in semiliterate, face-to-face cultures in which reading materials were scarce and the vast majority of knowledge was localized and context specific, there existed few sources of ideas and images for modeling the self outside those conveyed orally in daily life. The modern notion of the "self" as having a unique "inner" life with deeply personal memories did not yet exist.

If today's individually centered, subjective narratives produce persons who understand themselves as highly individuated beings separate from society, then what kinds of persons were produced in past narrative cultures adhering to different conventions? Could an examination of other narrative cultures point the way to understanding how the experience of human agency is culturally and historically contingent? I define agency here as "the capacity to act in a socially meaningful way," a definition that gives priority to the relationship between individual and society. In this essay I therefore ask: can an examination of past narratives provide insights into the relationship between self and society in previous cultures?

\section{Characteristics of Premodern Finnish Narratives and Voicelessness}

I base my discussion on over 1,750 recollected narratives and descriptions dealing with magic and the supernatural that were collected in Finland and neighboring Karelia ${ }^{9}$ in the late 
nineteenth and early twentieth centuries. I have chosen narratives on magic and the supernatural as my source data because they reveal much about personal goals, even those that were secret or socially disapproved. Narratives on magic and the supernatural are also excellent commentaries on social life in nineteenth-century Finland, routinely addressing conflict resolution, class boundaries, economic dependency, and expectations of aid and assistance. Finland was the last western European country to undergo the social transformations now collectively referred to as "modernization," and its folklore recorded in the period 1880-1960 reflects the strong influence of an older, premodern mode of narration. A successful national campaign of folklore collection that began in the last decades of the nineteenth century resulted in hundreds of thousands of memorates, belief legends, and oral histories recorded from agrarian commoners, comprising one of the largest collections of folklore in the world. These texts are housed in the Finnish Literature Society Folklore Archives in Helsinki.

There were four main ways in which conventions for nineteenth- and early twentiethcentury Finnish magic narratives diverged from those familiar from narratives in the modern West. First, these premodern narratives were embedded in local rural life; meaning that they made constant reference to locations, persons, social relationships, and events familiar to only a limited number of persons, a feature that at times renders them nearly unintelligible to the twenty-first-century researcher. For example, many characters were referred to simply by nickname, and although it appears to have been absolutely essential to ground the narrative in a local milieu by forging as many connections as possible to the human and topographical landmarks within it, time appears to have been much less important, and only occasionally did narrators bother to date the events occurring in narratives with any precision.

Second, stories composed in the older narrative mode tend to be constructed primarily 
through the dialogue spoken by their characters. Rather than distancing themselves from the social exchange as an objective observer and summarizer of the plot, narrators often repeated as if verbatim what others had said--often without linguistic markers or punctuation to indicate the start of the dialogue or a change in speaker. These narratives contain few references to the world outside the conversational dialogue, and the plot advances almost entirely through the exchange of lines spoken by characters. Third, the causal connections essential to understanding the narrative plots, especially when they are associated with magic, are often alluded to using euphemistic expressions understood only by members of the same narrative community. One of these expressions was to refer to magical harm as a "dog," a topic to which I return later in this essay. Due to the common use of such euphemisms, for the researcher it may be difficult to recognize when the narrator is talking about magic, witchcraft, or the supernatural.

A fourth tendency in the older narration of magic-related events was to posit not merely stable characters, but characters so fixed by their social roles that they are almost completely "flat," displaying little of the variation, spontaneity, and development that are essential to the assumed psychic makeup of characters in modern narrative. Narrative characters were routinely referred to simply as "the Old Man of Farm X," or "the Mistress of Farm Y." They were not presented as entitled to social recognition of their personal, individual distinctiveness. One farm mistress was portrayed as much like another, just as one farm master was much like his neighbor, because they were expected, due to their role and position within the farm household (but not due to their individuality) to have similar rights, responsibilities, goals, notions of both selffulfillment and roads to that self-fulfillment. Fixity is a premodern convention familiar from folktales and fairy tales, and contrasts with the identities of characters in modern novels, which are not given in advance but are viewed as an open-ended question, or which evolve over the 
course of the story (Ricoeur 195). The "inner" experiential world of these characters was rarely addressed, the focus being instead on character dialogue and depicted action. Human emotions were portrayed in a distant, nonempathic fashion, with fear and horror depicted as flight from the haunted site, hate and envy camouflaged as revenge, and regret and repentance expressed as finding no peace or walking the earth after death (Jauhiainen 18). With the exception of sorcerers, criminals, and other deviant or exceptional members of society, the motives, emotions, and thoughts of third-person characters were rarely explored in the narratives examined here.

Finnish narratives may have had relatively fixed characters, but there was one way in which they recognized and inscribed individual agency. In the narrative element I call "voice," some characters were allowed to express their own unique viewpoints, opinions, and experiences, thus portraying themselves as active agents within the narrative. I thus define "voice" as being located in, and originating from, the social recognition of persons as agents. Although in real life, personal agency can also be expressed through meaningful silences, gestures, and subversive practices that remain unspoken, voice is nonetheless the most common way for socially meaningful action to be inscribed in narratives. Yet not all characters were endowed with voice to an equal extent. In reading the source narratives, it becomes clear that if we ask the question: "who is telling the story?," "about whom?," we find, on the one hand, a consistent group of characters who were allowed to tell their own stories, while on the other, a different set of personae non grata who were not permitted to tell their story but were instead told about. I call this feature of narrative "voicelessness." Under certain conditions, voicelessness can also be found in narratives that allow characters to relate their own experiences of not being able to express themselves. An examination of voicelessness can provide important insights into how the experience of human agency is culturally and historically contingent, proceeding from 
different configurations of the relationship between individual and society. If, as I argue here, the locus and source of voice is a socially recognized self-as-agent, then a closer look at voicelessness in narrative can tell us something about the fragility or durability of the bond between individual and collectivity, a topic to which I return at the end of this essay.

In the narratives discussed here, the issue of voicelessness comes up most clearly in three situations. First, we find stories in which victims of sorcery retaliate with harmful magic and then confront the suspected witch. In these stories, the witches who are accused and confronted always admit their guilt and never claim to be innocent or wrongly accused. Second, in narratives recounting punishments faced by those who failed public testing rites (in other words, parish catechism examinations, ${ }^{10}$ court trials, village dances, and the moment at which newly married brides entered their husband's farm for the first time), persons used magic prior to these tests to ensure their "victory" by convincing themselves of being active agents with a voice, whereas those narrative characters who failed the "test" were no longer allowed in narratives to express themselves. Third, in stories of children, adolescents, or women ${ }^{11}$ who were lost in the

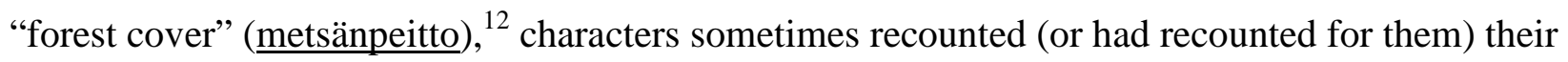
own experience of voicelessness, as in the following narrative:

My mother, Maija-Liisa, told many times in the old days how, as a young woman, she had been trapped in the forest cover. She was at that time a cowherd for Suurisuo farm. During this period it happened that [the old woman] Loukku-Maija stole nine varnished wooden spoons from the farm. The farm mistress had said to my mother: "If you go and ask Loukku-Maija to give back the spoons, I'll give you a piece of bread with cheese." And mother, who was only a foolish young girl, went and asked. Maija became furious and said: “Mark my words, you're going to remember this, my girl." The next day when my mother was out herding, she hung her knapsack with her supper on a pole and began to cut birch branches to make bathing whisks. Suddenly she felt how a strange force compelled her to leave the cows and provisions where they were and go straight into the heart of the forest. This happened on 
Monday. During the following days and nights she wandered continuously in the forest, trying to get home, but to no avail. Sometimes she came so close that Suurisuo farm could be seen in the distance, sometimes she encountered its cattle in the forest, but always the same mysterious force led her back into the forest. Once she came upon [the boys named] Hurska and Laaksonen, who were herding cows and sitting around a bonfire. Mother went to sit between them and warmed herself. She couldn't understand why the boys didn't say anything to her, she herself tried to speak, but no words came out of her mouth. Another time she ended up at a spring near the Suurisuo meadows. After drinking from the spring, mother sat on a tussock to remove a splinter from her foot. Then the master of Suurisuo farm came from the meadow to drink from the spring. He looked around for a moment, having seen fresh footprints and a wet birch-bark ladle. Mother, who was still unable to speak, had thought: "why doesn't that farm master speak to me either?" Later the farm master told how he had wondered where that large tree stump near the spring had appeared from. Mother had appeared to his eyes as a tree stump. The entire village had been out looking for mother the entire time, but to no avail. She was found only after somebody went to fetch [the sorcerer] Taavetti Haasi-aho to release her from the forest cover. This happened on Friday. Thus mother had gone without food, except for berries, and without sleep for four days. Everything happened because of Loukku-Maija's revenge, since her family was from Rutja [in Lapland]. (SKS KRA Saarijärvi. 1935. Otto Harju KRK 69:46. --Elina Harju, fifty-eight years. Emphasis mine)

Wandering into the forest and staying there for several days was not considered something that persons normally undertook of their own free will. Aside from concrete dangers such as hunger, accidental injury, and forest predators, the forest represented a danger zone conceived to be fundamentally different from the world of humans. In fact, the contrast between the forest and the human sphere of habitation was one of the most fundamental dichotomies in Finnish folk thought (see Tarkka; Stark, Peasants, Pilgrims, and Sacred Promises). In forestcover narratives, the lost person was trapped within the forest spirit's sphere of influence, which was in clear opposition to "being among people." Persons released from the forest cover suddenly appeared in, or made their way back to "the world of people" (ihmisten ilmoille). As 
can be seen in the above story, lost persons in forest cover narratives were described as unable to speak or reveal themselves to searchers, to whom they were invisible or appeared to be tree stumps or large stones.

Narrative Coding of Agency, Emotion, and Causality

To answer the question of whether narratives can provide insights into the relationship between self and society in the premodern era requires that a large corpus of narratives be available for study. It also requires that the researcher pay attention to how self, personhood, and agency are encoded within them, with particular attention to: (1) how intention, desire, emotion, and sensory capabilities were seen to operate and affect the physical and social world; (2) what other causeand-effect relationships were seen to be in play in everyday life (not all of them corresponding to our own understanding of reality); and (3) how capacity for embodied action was seen to be enabled or repressed in different contexts.

For example, losing one's way in the forest was not considered a natural occurrence, but was seen to be deliberately caused by either the forest or by another person, especially if that person became angry and the target of his/her anger was a child or adolescent. Before young persons lost their way in the forest, an adult or evil-minded neighbor was often believed to have cast a spell on them or cursed them, possibly uttering the oath "may the Devil take you." As one farm mistress born in 1878 explained at the end of such a narrative, "my mother spoke of this often as a true story and said that one must never curse at children, or they will end up in the forest cover."13 The following narrative recorded from an elderly man in 1961 expresses both the concept of anger as the catalyst propelling the child into the forest, and the child's recollected experience of voicelessness while in the forest: ${ }^{14}$ 
When I was small boy, I liked to lie on the grass of our yard and peer at the sky. Once, when I was watching how the rascally angels romped on high on their mattresses of soft down, my father came to the steps of the cottage and thundered at me: “confounded boy, you lie about and what's more, you'll ruin your eyes! You may go and fetch the cattle home. Take a slice of buttered bread with you and be on your way." So, I left in a sullen mood. When I had climbed the steep slope of Isokorvi, there was a black ram in my path, with its head cocked to one side. I threw a stone at it. Then the ram turned and bleated. Oh dear. Soon the Old Woman of the Forest came to me and whisked a blue scarf over me. I panicked: oh no, I'm supposed to bring the cows home. Father ordered it. [The old woman of the forest said:] "You're not yet any good as a cowherd, if you throw a stone at my sheep. I'm going to turn you into a sack of straw.” Thus I spent many days and nights in the forest. I saw how the folk of the village searched for me. Somebody leapt across a ditch in which I was lying. I could not get a word out of my mouth. Once, I wandered to my home pasture. On a stone had been placed a half loaf of bread and a bowl of soured milk. Who? Mother? Only mother could have thought of such a thing. And there mother was carrying twigs and brushwood to the cooking hut. Her tears sizzled on the fire she kindled. She was mourning her son Eljas. Evening came at the end of a long day. I watched as the villagers returned home from the fields and heated their saunas. Then--piumm, paumm--the ringing of the Saturday church bells boomed. I clasped my hands. How white and thin my fingers were. And how filthy my shirt. I had become visible. Homeward, homeward, the forest no longer held me. "Are you our boy Eljas?" asked my mother and father. "Who else? And now I'm hungry." (SKS KRA Kaustinen. 1961. Hilda Peltoniemi TK 74:2. -The memories of an old man from Tastula farm)

Since the question of what actually happened to these lost persons is, naturally, impossible to answer solely on the basis of the narratives alone, I concentrate here on the culturespecific ways in which agency and causality were represented within them. For example, it can be seen from forest cover stories that anger in rural-traditional Finnish culture was not merely a physiological response or inner emotive state; it was a mode of action that was seen to have tangible consequences for other persons. When sorcerers or persons working harmful magic 
became angry, they could cause bodily harm, mental illness, or even death to their intended target. Their anger was believed to be especially powerful if they possessed hard, strong, or "raised" luonto, a supernatural force believed to be located within the human body/self (Stark, Magical Self 262-69). A story recorded in 1939 tells of a farmhand who, despite warnings from onlookers, vandalized a bird trap set by an elderly male sorcerer. As the famous sorcerer Pekka Tuovinen recounted: "at this the old man became furious. And later, when the farmhand went insane for the rest of his life, the old man said, 'I became too angry, he cannot be saved,' when he was asked to grant mercy." 15 In another story, a man who verbally offended the sorcerer known as "Doctor Hirvonen" (= Juho Hirvonen, 1866-1930) died of a hemorrhage the same night. According to the narrator, "Doctor Hirvonen said of himself that the person at whom he became angry would die right away." ${ }^{\prime 16}$ Persons in authority, especially farm masters and clergymen, were similarly thought to be able to cause physical harm through their anger alone, as the following story of a clergyman officiating at a parish catechism examination illustrates:

About fifty years ago at a catechism exam, parson Grönberg was severely angry over the poor reading ability of Heikki, the son of a neighboring farm. Immediately following the catechism exam, Heikki became ill in such a way that his back was in severe pain and his jaws locked up so that it was impossible to give him food without pulling out his teeth. Heikki's mother, who was a strong believer in magic, said: "The parson's curses are in the boy." (SKS KRA Lappajärvi. 1938. Heikki Toivonen KT 178:1)

The effects of anger were not necessarily seen to be under the sorcerer's control (Stark, Magical Self 220-21). To give just one example, in a narrative recorded in 1938, a woman was said to have caused a small infant to cry incessantly through supernatural means because she had felt herself insulted by the infant's mother. She was reported to have later said, "it is my fault, 
but I can do nothing for it. When I feel insulted, it has an evil effect." ${ }^{\prime 1}$ Understanding how desires, intentions, and emotions such as anger were thought to operate in this culture helps to unravel the mystery of why some persons who worked harmful magic in older Finnish narratives were given a voice, and why some were not. Sorcerers who were usually male (tietäjä in Finnish) and sought to punish malicious witches (either male or female) on behalf of a victimized client, or who took revenge on someone who had insulted them, consistently expressed through narrative their own intentions, desires, and justifications for their actions. One of the most common ways in which tietäjäs aided clients who were victims of witchcraft was to "send back the dog" (= agent of magical harm) to attack the witch who had originally sent it. The "dog" was thought to then attack its master or mistress even more furiously than it had attacked its original victim, causing sudden pain, illness, or even death, following the tietäjä's instructions. According to the natural laws of magic, this countersorcery was believed to automatically target the guilty and bypass the innocent, finding the witch even if others in the community had not yet identified her or him. "Sending back the dog" was thus considered to be an effective means of identifying and punishing unknown perpetrators of witchcraft (Stark, Magical Self 180-86). In these narratives, whoever then fell ill or was injured shortly after the "dog” was sent back by the tietäjä tended to confess his or her guilt when confronted with accusations of witchcraft, as illustrated in the following narrative:

There on our farm we had [an elderly female] cottager [living on our land], and a snake was always biting our livestock, since it had been summoned by the cottager. My father said, "I'll surely send that dog to its home," and it was no time at all before the old neighbor woman went to bathe herself in our sauna, and on her way to the sauna a snake wrapped itself around her leg. Father was fetched to look at the leg, and he said to the old woman, "what were you doing sending a summoned snake to bite our livestock?" Well, then the old woman confessed, and my father 
healed her leg. (SKS KRA Valtimo. 1939. J. Hautala 1418. --Leena Hakkarainen, fifty-six years)

The fact that suspected witches in these narratives nearly always admitted their guilt makes more sense when we take a closer look at local understandings of causality, which can be read from the larger narrative corpus. While it certainly served the aims of narrative closure to show that the target of revenge was, in fact, guilty of magical harm and that counter-sorcery had enabled justice to prevail, firsthand witnesses' accounts raise the question of whether perhaps suspected witches did, after all, internalize the blame laid at their feet. If we take into account the fact that (1) the older Finnish worldview gave little credence to notions of chance or coincidence, in other words, it was highly deterministic in its insistence that all out-of-the-ordinary occurrences had a specific, usually supernatural cause (Stark, Magical Self 43-44); (2) the "dog" or magical harm sent back in counter-sorcery to attack its sender or "master" was believed to function with unerring justice to bypass the innocent and target only the guilty; (3) the person to whom the "dog" returned, who fell ill or received injury, usually had a well-known history of quarrels with the victim (ibid. 200-218); and finally (4) anger was widely believed to be sufficient to cause real harm in and of itself, and was not necessarily under the angered person's control; then persons who were identified as the perpetrators of magical harm, especially if they had some quarrel with the victim, may well have accepted the accumulated evidence against them as incontrovertible and taken responsibility for the sorcery.

\section{Voicelessness and Shame}

Narratives regarding magic and the supernatural make it clear that another important threat to personal agency was the shame that could result from failure to successfully negotiate public testing rites. The concept of public testing rites is one that I have constructed by taking into 
account all of the social contexts in which a single magic incantation motif ("I am a wolf and you are all sheep") was reported to have been used to empower the user. Of the sixty-three recorded variants of this motif that I have found, twenty-five were described as incantations to be uttered by defendants at local court trials in which the magic-user addressed the judge and/or jury. Fourteen examples were described as incantations used by persons undergoing parish catechism examinations, addressing the clergyman conducting the exam; fourteen by brides entering the home of their husband's kin for the first time; nine by unmarried girls at village dances competing with other girls to find a suitor and addressing the peer group; and one by a suitor in the home of the girl he was courting, addressing the girl's kin. In all of these contexts of use, tested persons needed to ensure that they were effective in expressing themselves either verbally or through physical skill. The persons to whom the incantation-user directed the utterance were social authorities: the judge and/or jury, village parson, a bride's in-laws, or the peer group ${ }^{18}$ that assessed a girl's or boy's success at dance events. In the Finnish-Karelian charm tradition, incantations are almost never used for more than one purpose but are tailored to specific contexts. The fact that ordinary persons resisted the power of social authorities in all of these situations by reciting variations on essentially the same verbal formula indicates that users perceived these situations to be comparable arenas of power. Public testing situations were occasions on which an individual's future social standing hung in the balance. If someone failed the test, that person could be forced to undergo public shaming, which could damage his/her reputation and worth in the eyes of the others. Those who failed the parish catechism examination, for example, suffered humiliation and often physical or psychological violence at the hands of the clergyman conducting the exam, who might order slower readers under the table as a mark of their disgrace, or shout at those whose ability was substandard. Those who were 
judged to be poor readers could also be put in the stocks in front of the church where anyone was allowed to spit on them as they walked by. Examinees could be whipped or beaten, forced to kneel on dried beans or peas, or grabbed by the hair, which in the mid-nineteenth century was still worn long on men as well as women (Vaara 42, 46): ${ }^{19}$

And the parsons and parish clerks were allowed to treat as shamelessly as they could those who were unable to read or who were so afraid that they never got a chance to utter what they were able to read, and large men were thrust under the table and boxed on the ears. (SKS KRA Ruovesi. 1938. Aino Autio PK 7:1351)

A certain parson ordered a full-grown man to kneel before him, he took a fistful of the man's long hair and then shook the man's head back and forth and said in full view and hearing of all: "you miserable layabout." No wonder, then, that catechism exams became frightening occasions and people would rather go to the parsonage to read for the minister, since there one could not be shamed in front of others. (SKS KRA Asikkala. 1938. Einar Toppola PK $10: 1677)$

Those convicted in court of crimes, for their part, faced imprisonment, fines, whipping, banishment to Siberia, and/or public shaming at church by being forced to "sit away their honor" on what was known as the black bench in full view of everyone. New brides entering their husband's birth home were subject to close scrutiny by their husband's female relatives, and were in danger of being made to occupy the lowest status within the household andto do the most arduous work (Stark-Arola 97). Dances, which provided a key opportunity for young men and young women to meet their future partners in marriage, ${ }^{20}$ were an arena in which young women's physical fitness, social skills, and beauty were under evaluation, and in southeastern Finland, girls who were rejected or abandoned by male dance partners might have their names shouted out loud for everyone at the dance to hear, a humiliation that could hurt their chances of 
making a good marriage (Stark, Magical Self 437).

Premodern testing situations were mechanisms through which the social hierarchy was organized and reordered, and social mores perpetuated. Catechism exams strove to ensure that community members were good Protestants familiar with biblical teachings, while court trials dealt with persons who had violated the social order. Through evaluations made at village dances, undesirable potential brides (those who were ailing, weak, physically or socially inept) were excluded from the pool of marriageable young women--an important process in the reproduction of viable farm household units through marriage. The reference point for discipline and punishment in these testing rites was something that could be called the moral community, a symbolic space from which those who "failed" in the testing arenas of catechism exams and court trials could be banished, and this banishment was dreaded above all things. According to several informants, the catechism exam ranked as one of the "hardest" days of year along with the pig slaughter and oat threshing (Stark, Magical Self 385-86).

With regard to voice and voicelessness, those persons who failed a public testing rite were never given the opportunity as characters in narrative to verbally express their opinions, feelings, or motivations. Their selfhood, their very perspective on the world, remained hidden from view. Accounts in which the "losers" of testing rites were publicly shamed or physically punished were ultimately portrayals of their loss of personhood and agency--in other words, the destruction of the socially recognized self-as-agent. .

Nevertheless, we can glimpse how the possibility of voicelessness was resisted by those who underwent testing rites by looking at the magic rites they employed in these situations. Testing situations made it difficult for individuals to withstandthe perception of themselves as compliant and submissive in the face of social authority because there were no means by which 
examinees or defendants could directly confront or defy authorities and still pass the test or win the court case. Because of this, resistance to subordination in testing situations often took the form of masked resistance through magic.

In reporting on life in southeastern Finland in the 1840s from firsthand observation, Eljas Raussi (1800-1866) commented on the fear the rural folk experienced when they were not able to defend themselves verbally in the courtroom, and the advice given by older persons to use magic in this situation:

Those who do not wish to go to court are those who are unfamiliar with it and those who are fearful, because they are aware of their ignorance and that much they know about trials, that the law often sentences people to pay fines. .

. They have often heard that he who presides over the trial can take away their luonto [a supernatural force believed to be located within the human body/self], so that many, it is said, have not been able to open their mouths out of sheer bewilderment. To fortify them against this sort of bewilderment they receive from the old people the following advice and magic trick: when they go through the door into the courthouse, first of all they should look at the ceiling and then into the eyes of the judge with the silent saying on their lips: "the readers of the law are sheep."(Raussi 458)

Jean Comaroff has shown that rather than outright confrontation, resistance can often take forms whose purpose is to prevent the dominant system from penetrating the self. Magic rites and incantations were an ideal means of managing self-perception and resisting subordination by social authorities because first, for those versed in the incantation tradition, the brief verbal variants of "I am a wolf and you are all sheep" referred to a broad universe of mental associations and imagery within Finnish folklore in which the wolf was a powerful, liberated figure standing beyond the reach of social authority (Stark-Arola 184-91). Second, magic was secret. Before persons could defy ritualized subordination, they first had to control their own 
emotional state, particularly their fear response. Through concealment, secret knowledge becomes something possessed, and this possession distinguishes the possessor from other persons (Luhrmann). The possession of secret knowledge invests the individual with personal power and redefines him/her as a social actor, both of which neutralize the aims of ritual subordination in public testing rites. In early modern theaters of power such as dances, court trials, and catechism exams, the use of secret magic rituals allowed the users to resist subordination and shaming by making them active subjects in their own minds. Defendants in court trials, for instance, used magical objects and secret incantations in order to "defeat" the judge, jury, and plaintiff and thereby go free, as in the following description from northwestern Finland:

\section{Court trial}

When one left the house, then one was armed, if not with silver objects, then with silver coins and one had to go to the cemetery and one had to drop the silver three times at the foot of three grave markers and say:

Nousepa ukko noitumaan Arise, old man, to work witchery

Wihollista villihtemään $\quad$ To agitate my enemy

Minä vallalliseksi To make me prevail

Ja sinä vallattomaksi And to make you wild

Riitamiestä riipomaan To make my adversary hang,

Minä voitolliseksi viskomaa. $\quad$ And me victorious!

One was supposed to put the money in the "poor boy" [= wooden collection box], and then when one went into the courthouse, one had to say there quietly, "I am a wolf, you are a sheep," and look into the eyes of the judge, and to the ceiling while speaking. Then one didn't sound panicked, when one had to speak in his own defense, and would win. (SKS KRA Pyhäjärvi Ol. 1884. Kaarle Krohn 2452. --Juho Kananen)

Magical means of resisting subordination were employed solely by persons undergoing testing 
rites. Persons who had already "failed" testing rites were never reported as uttering incantations or attempting to use magic as a form of resistance. The fact that persons still undergoing testing situations were construed as agents through their use of magic is understandable, since from the perspective of rural inhabitants, anyone might be tested in the annual catechism exam or as a defendant in court, but only a few unfortunates would emerge as "losers." This meant that tested persons--at least until they failed the test--could be seen by others as "people like me," active agents in society.

\section{Voicelessness as Detachment from Society}

In the narratives of accused witches and public testing rites, voice and voicelessness serve a number of rhetorical aims, in other words, the agency of narrated characters was tailored to fit certain cultural master plots in order to enhance the rhetorical force of the narrative. In the case of accused witches, their acquiescence to the interpretation put forth by the perceived victim and acceptance of blame facilitated the moral closure of the tale (that is, evil gets its just reward), and in the case of public testing rites, voicelessness underscored the fact that the "loser" of the test had no right and no power to protest his/her new status. Forest cover narratives differ in this regard in that within them, the narrative character is allowed to describe his/her own brief experience of voicelessness, which--since it befell a solitary person in the wilderness--would have been difficult to express using another narrative device.

Yet I argue that the representation of voicelessness in forest cover narratives shares an important feature with that found in other narrative themes. Laying aside the rhetorical imperatives of voicelessness in these narratives, a closer examination of the context in which voicelessness occurs points to an even deeper underlying commonality--namely, the detachment 
of the individual from society. In all premodern Finnish narratives dealing with voicelessness, the tacit collective consensus that gave persons their meaningful social identity, their basis for voice and social agency, is depicted as having been stripped away--either just before persons entered the forest, after they failed an important social "test," or when they became suspected of witchcraft. Detachment typically occurred when the character in question became the target of another's anger or malice that was expressed as curses, physical punishment, or countersorcery with violent intent.

Premodern conventions within Finnish narratives seem to have dictated that in order to be given a narrative voice, in other words a culturally validated declaration of agency within a story, persons could not be detached from their community. The three different narrative contexts of voicelessness do not, however, approach this link to social detachment from the same direction. In narratives on public testing rites and counter-sorcery to punish witches, it is clear that the characters who lack a voice have first been banished from the moral community--at least temporarily--because their behavior has met with social disapproval. Because their banishment has been publicly witnessed by others and talked about within the community, there is no need for their experience of voicelessness to be accessible from the narrative itself. In forest-cover narratives, by contrast, the subjective experience of voicelessness must be expressed in the narrative, because the lost person's detachment from society, although hinted at by his/her physical isolation in the wilderness, could not be observed by others. Indeed for the researcher as well, a closer look at the narrative corpus regarding forest cover experiences is needed in order to elucidate what sort of detachment is at issue here.

Let us first address the issues raised by narratives on public testing rites and countersorcery to punish witches. Since representations of punished or shamed persons in the early 
modern era come to us only through narratives in which they are given no voice, we cannot know with certainty what the person accused of witchcraft or made to sit under the table at the catechism exam experienced. We may speculate, however, that if people construct their sense of self and identity through narrative templates, punished or shamed persons in nineteenth- and early twentieth-century Finland may have found it difficult to see themselves as agents or construct an intelligible account of their agency if their culture did not provide narratives from which to model such an account. In other words, at some level, narrative conventions for talking about accused witches and "losers" in public testing rites may have rendered these persons nonagents in equivalent real-life situations.

When we look at the most typical experiences of being trapped in the forest cover, the fact that we are dealing with detachment from society is suggested by three narrative elements. First, all that was needed to set the sequence of events in motion was an angry word or a profanity directed at a child or adolescent by an adult, and when these young persons were sent into the forest on an errand, they became unable to find their way back to "the world of people." Second, lost persons who were deprived of their everyday networks of human contact perceived themselves to lose the qualities that made them recognizable human agents. In their subjective experiences, their ability to communicate with and be recognized, their sense of direction, and need for food, warmth, and human company were all profoundly altered. They saw themselves take on the characteristics of the forest, transformed into beings that were mute, passive, and invisible; impressions that were reinforced when searchers later reported that the lost person had appeared to their eyes as a stone or tree stump. Third, lost persons had difficulty in reattaching to society and reentering the community after being lost in the forest. The difficulty of reattachment was expressed on several levels: lost persons did not recognize places that should have been 
familiar, they felt an overwhelming urge to run away from human searchers, encountered anthropomorphic figures that forbade or prevented them from returning home or making contact with other humans, and they did not feel the bodily sensations (hunger, cold, fatigue) that would have compelled them to seek human shelter. This was not because "trapped" persons were enjoying a new sense of liberation during their sojourn in the forest--there is nothing in the narratives to suggest such an interpretation--rather, the experience was repeatedly depicted as a kind of limbo state in which persons lost all capacity to act and decide for themselves. Because lost persons were unable to return to home and community on their own initiative, other persons had to help them reenter the "world of people." Neighbors had to catch or find stray children running wild, sorcerers had to use magic to force the forest to release its prisoner, and clergymen had to extend the power of the church's domain over the forest by blessing it or ringing church bells that could be heard kilometers away. All of this suggests that being separated from the human community for an extended period of time was understood at some level to sever the bond that connected persons--especially young persons without established roles or statuses--to society.

What do these narratives of voicelessness and social detachment tell us about the relationship between self and society in premodern Finnish rural culture? Narratives in which social detachment is expressed as voicelessness highlight how important it was for premodern individuals to be firmly embedded in a community in order for them to act as agents, but also how fragile the bond between individual and collectivity was perceived to be. Whether the collectivity took the form of a moral community or the man-made environment of the "world of people," individuals were understood to possess a voice only if their place within the collectivity was relatively secure, in other words if they were in harmonious relations with others and held 
positions of relative authority. Children and youth with little authority, persons being tested publicly and those known to harbor grudges and make threats against their neighbors were all at risk of being forcibly disconnected from the community, however temporarily. This suggests that the importance of fixity, of firm and well-recognized social roles for narrative characters, may have applied not only to the narrative world, but to the real world as well.

Nineteenth-century Finnish rural inhabitants were directly dependent upon other persons in face-to-face relationships and, with the exception of landless laborers and beggars, were tied to farms or crofts. This forced them to live in proximity with neighbors regardless of quarrels, even long-term feuds, between them. Even the itinerant poor were dependent upon the good will of others in their locality; their mobility was more a matter of economic necessity rather than freedom to forge social relations of their own choosing. It must be kept in mind that privacy, too, was practically unknown in a society in which dwelling spaces were small and nearly all labors shared (Pohjola-Vilkuna 76). In the Finnish countryside, persons lived, ate, and slept during much of the year in the same space or even in the same bed. In more densely settled villages, a household's activities were widely known to its neighbors in great detail, and weddings, funerals, even courtship tended to be highly public affairs, involving everyone in the community. There were very few activities in daily life that required solitude or privacy, and in fact, according to a female informant from southwestern Finland born in 1863, "everything which is done in secret is a sin." ${ }^{21}$ Behaving according to the expectations of others in order to maintain one's social standing seems to have absorbed a great deal of people's time and energy, resulting in little opportunity to engage in self-reflection. The intersubjective nature of the individual embedded in the community was reinforced by the fact that persons did not possess an objectively ascribed identity such as that assigned to citizens of modern nation-states, visible from identity cards or 
driver's licenses, for instance. In nineteenth-century rural Finland, an individual's personhood depended solely on recognition and evaluation from others in the local community. Persons could not close themselves off from others, be excluded by others, or be accidentally separated from others, without losing their status--and possibly their self-perception--of being an agent. By contrast, modern transportation and communications, bureaucratic institutions, and notions of society as founded on individuals entitled to universal rights has meant that ideally, for the modern able-bodied adult, social recognition of agency is guaranteed and is not directly dependent on the attitudes or approval of others in one's local community. Yet a multitude of persons in the present day fall invisibly through the cracks inherent in our late modern system of individual entitlement. Refugees, migrants, sexual and gender minorities, and groups underprivileged by age, ethnicity, and socioeconomic status may find themselves trapped in forgotten spaces of discrimination, incomprehension, and fearful silence. The findings of this premodern case study suggest avenues of fruitful exploration both in historical settings and in present-day contexts, and the notions of voice and voicelessness elaborated here represent useful conceptual tools for exploring the ways in which personal agency is understood and experienced, and in what contexts actors lose their capacity to act in a meaningful way.

Laura Stark is Professor of Ethnology in the Department of History and Ethnology at the University of Jyväskylä, Finland. She has authored several books on nineteenth-century rural Finland, most recently The Magical Self: Body, Society, and the Supernatural in Early Modern Rural Finland (2006) and The Limits of Patriarchy: How Female Networks of Pilfering and Gossip Sparked the First Debates on Rural Gender Rights in the 19th-Century Finnish-Language Press (2011). 
Archival Materials Cited

SKS KRA = Folklore Archives of the Finnish Literature Society, Helsinki.

\section{Works Cited}

Abbott, H. Porter. The Cambridge Introduction to Narrative. Cambridge: Cambridge UP, 2002.

Bakhtin, Mikhail. The Dialogic Imagination: Four Essays by M. M. Bakhtin. Ed. Michael Holquist. Austin: U of Texas P, 1981.

Barthes, Roland. "Introduction to the Structural Analysis of Narratives." A Barthes Reader. Ed. Susan Sontag. New York: Hill and Wang, 1982 [1966]. 251-52.

Comaroff, Jean. Body of Power, Spirit of Resistance: The Culture and History of a South African People. Chicago: U of Chicago P, 1985.

Geertz, Clifford. The Interpretation of Cultures. New York: Basic, 1973.

Gergen, Kenneth. An Invitation to Social Construction. London: Sage, 1999.

Giddens, Anthony. Modernity and Self-Identity: Self and Society in the Late Modern Age. Cambridge: Polity, 1991.

Greenblatt, Stephen. "Fiction and Friction.” Reconstructing Individualism: Autonomy, Individuality, and the Self in Western Thought. Ed. Thomas C. Heller, Morton Sosna, and David E. Wellbery. Stanford: Stanford UP, 1986. 30-52.

Harré, Rom. Personal Being: A Theory for a Corporal Psychology. Oxford: Blackwell, 1983.

Helsti, Hilkka, Laura Stark, \& Saara Tuomaala (eds.). Modernisaatio ja kansan kokemus Suomessa 1860-1960. Helsinki: Finnish Literature Society, 2006.

Jauhiainen, Marjatta. The Type and Motif Index of Finnish Belief Legends and Memorates. FF Communications 268. Helsinki: Academia Scientiarum Fennica, 1998. 
Kreiswirth, Martin. "Merely Telling Stories? Narrative and Knowledge in the Human Sciences." Poetics Today 21 (2000): 293-318.

Luhrmann, Tanya. “The Magic of Secrecy.” Ethos 17.2 (1989): 131-65.

Lyons, John O. The Invention of the Self: The Hinge of Consciousness in the Eighteenth Century. Carbondale: Southern Illinois UP, 1978.

Nussbaum, Martha. "Narrative Emotions: Beckett's Genealogy of Love.” Ethics 98.2 (1988): 225-254.

Pohjola-Vilkuna, Kirsi. Eros kylässä: Maaseudun luvaton seksuaalisuus vuosisadan vaihteessa. Helsinki: Finnish Literature Society, 1995.

Potter, Jonathan. "Discourse Analysis and Constructionist Approaches: Theoretical Background." Handbook of Qualitative Research Methods for Psychology and the Social Sciences. Ed. John T. E. Richardson. Leicester: BPS Books, 1996. 125-40.

Raussi, Eljas. Virolahden kansanelämää 1840-luvulla. Helsinki: Finnish Literature Society, 1966.

Ricouer, Paul. "Narrative Identity.” On Paul Ricoeur: Narrative and Interpretation. Ed. David Wood. London: Routledge, 1991. 188-99.

Rose, Nikolas. “Assembling the Modern Self.” Rewriting the Self: Histories from the

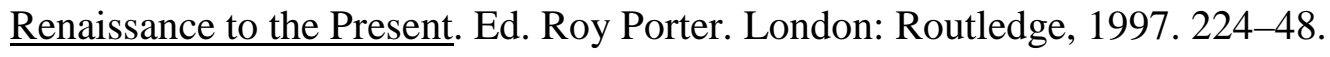

Ross, E., and R. Rapp. "Sex and Society: A Research Note from Social History and Anthropology.” Desire: The Politics of Sexuality. Ed. A. Snitow, C. Stansell, and S. Thompson. London: Virago, 1984. 51-73.

Royce, Anya Peterson. The Anthropology of Dance. Bloomington: U of Indiana P, 1977.

Sarmela, Matti. Reciprocity Systems of the Rural Society in the Finnish-Karelian Culture Area with Special Reference to the Social Intercourse of the Youth. Trans. Matti T. Salo. FF Communications 207. Helsinki: Academia Scientiarum Fennica, 1969. 
Shotter, John. "The Social Construction of Our Inner Selves." Journal of Constructivist Psychology 10.1 (1997): 7-24.

SKVR = Suomen Kansan Vanhat Runot I-XV. Helsinki: Finnish Literature Society, 1908-97.

Stark, Laura. The Magical Self: Body, Society and the Supernatural in Early Modern Rural Finland. Folklore Fellows Communications 290. Helsinki: Academia Scientiarum Fennica, 2006.

---. Peasants, Pilgrims, and Sacred Promises: Ritual and the Supernatural in Orthodox Karelian Folk Religion. Helsinki: Finnish Literature Society, 2002.

Stark-Arola, Laura. Magic, Body, and Social Order: The Construction of Gender through Women's Private Rituals in Traditional Finland. Helsinki: Finnish Literature Society, 1998.

Swanson, Gillian. "Memory, Subjectivity and Intimacy: The Historical Formation of the Modern Self and Writing of Female Autobiography." Memory and Methodology. Ed. Susanna Radstone. Oxford: Berg, 2000. 111-32.

Tarkka, Lotte. "Sense of the Forest: Nature and Gender in Karelian Oral Poetry." Gender and Folklore: Perspectives on Finnish and Karelian Culture. Ed. Satu Apo, Aili Nenola, and Laura Stark-Arola. Helsinki: Finnish Literature Society, 1998. 92-142.

Vaara, Väinö. Kansanopetus- ja valistustyö Valkealassa. Mikkeli: Valkealan Opettajayhdistys, 1919.

Worthington, Kim L. Self as Narrative: Subjectivity and Community in Contemporary Fiction. Oxford: Clarendon P, 1996. 


\section{Notes}

${ }^{2}$ In the modern West, according to social psychologist Kenneth Gergen (68-70), narrative conventions include establishing a valued endpoint, selecting elements relevant to the endpoint, ordering events according to logics that are culturally specific (importance, interest value, temporal and spatial proximity to narrator, temporal linearity), creating characters with stable identities, making explanatory causal linkages, and providing signs demarcating the beginning and end of the story.

${ }^{4}$ By the term "self" I am not implying an object that can be isolated for study within realist paradigms of social science, but an abstractum, a metaphor for the modern experience of constructing our subjectivity according to a certain ideology of individualism, as well as sets of stories people tell about themselves, or discursive practices for dealing with one another as moral and accountable selves (Greenblatt; Potter, Harré, Shotter). The "self" is thus a shorthand term for a set of strategies in which persons strive for the appearance and impression of internal coherence, both logical and temporal. Yet selfhood is not a fiction, if by fiction we mean that it is untrue or has no ontological existence. Rather, the self should be seen as an active interpretive process (Worthington 13).

${ }^{6}$ See also Gergen $68-70$.

${ }^{7}$ Stephen Greenblatt (35) has argued that the principle of entitlement, which he defines as "a mode of protection for licensed particularity," lies at the core of the modern ideology of individualism.

${ }^{8}$ I define "premodern" in the Finnish context as prior to the 1860s, the decade when a number of decisive political, economic, and social transformations occurred that opened the way for new possibilities in industry and commerce. These changes altered the structure and rhythm of nineteenth-century agrarian communities, communities in which, with the exception of the Bible and Catechism, narratives had previously been transmitted almost entirely through word of mouth. Even so, many of the major effects of modernization and industrialization were not felt in remote parts of rural Finland until the 1930s (see Helsti et al.)

${ }^{9}$ Karelia is the area straddling Finland's eastern border region, which historically has been closely related, both linguistically and culturally, to Finland. Today, some parts of Karelia reside within Finland's current borders, while others reside within Russia.

${ }^{10}$ In parish catechism examinations, church officials visited each municipality once per year in order to examine the reading abilities of each child--and some adults--living therein.

${ }^{11}$ Men who frequently moved around in the forest to hunt, fish, or trap were almost never depicted as losing their way in the wilderness.

12 "Forest cover" was the belief that the forest was capable of imprisoning persons or livestock within it so that searchers could not see them (or mistook them for elements in the forest landscape). Persons who lost their way in the forest later reported having encountered strange anthropomorphic or zoomorphic beings who accompanied them, and in the case of children, even fed them. These strange beings, however, usually prevented the lost person from announcing themselves to persons searching for them (see Stark, Magical Self 357-80).

${ }^{13}$ SKS KRA Sievi. 1937. L. Jakola 525. --Selma Jakola, farm mistress, b. 1878.

${ }^{14}$ See also SKS KRA Salmi. 1935. A. V. Rantasalo 636. --Irinja Murto, fifty-nine years; SKS KRA Kitee. 1921. Pekka Vauhkonen VK 107:1, pp. 32-33.

${ }^{15}$ SKS KRA Valtimo. 1939. Jorma Partanen 1124. --Pekka Tuovinen, forty-five years.

${ }^{16}$ SKS KRA Liperi. 1935-36. Tommi Korhola KRK 157:143. --Aapeli Ihalainen, forty-three years.

${ }^{17}$ SKS KRA Pylkönmäki. 1938. Otto Harju 1603. --Miina Leustu, b. 1870.

${ }^{18}$ The village peer group was a powerful social institution in agrarian, premodern Europe that regulated who was eligible to marry, in what historian Ellen Ross and anthropologist Rayna Rapp (58) have called a "highly ritualized management of celibacy and courtship." For more on shaming punishments enforced by the peer group in nineteenth-century Finland and Karelia, see Sarmela 196.

${ }^{19}$ See also SKVR XII2 13273. Säkkijärvi. 1938. --H. Suni.

${ }^{20}$ Physical and mental fitness, strength, and agility were important attributes in a potential marriage partner, and a lack of these attributes could not be hidden from partners while dancing (Royce 199-200). Outside of actual farm labor, dance was often the only context for judging the strength and endurance of other persons, which was important since women would have to perform heavy labor on the farm after marriage.

${ }^{21}$ SKS KRA Sahalahti. 1940. Helmi Helminen 372. --Hanna Helin, seventy-seven years. 